\title{
Translating National Ideology in China English - A Diachronic Investigation of Beijing Review
}

\author{
Mingming YUAN (Corresponding author) \\ English Language Center, Shantou University, 243 Daxue Road, Shantou, Guangdong, China \\ E-mail: mmyuan@stu.edu.cn
}

\begin{abstract}
Received: 11-02-2016
Accepted: 18-04-2016

Advance Access Published: May 2016

Published: 01-07-2016

doi:10.7575/aiac.ijalel.v.5n.4p.79

URL: http://dx.doi.org/10.7575/aiac.ijalel.v.5n.4p.79

The research is financed by Guangdong Tertiary Innovative Talents Project. No. 2015 WQNCX032 and Shantou University Fund for Research in Liberal Arts No. SR15002.
\end{abstract}

\begin{abstract}
As an expanding circle variety, the distinctive features of China English have been identified as: idiom transfers, loan translations of political terms, connotation changes, semantic shifts, and the orientalized style of discourse. While its characteristics are agreed upon by most researchers, China English does not always display these characteristics to the same extent. A Comparison of articles in Beijing Review (the first English weekly news magazine in the PRC for international consumption) over the years of 1958-2015 shows both endonormative (towards the "Chinese" characteristics) and exonormative (towards "international English") movements. In general, earlier issues, especially those during the Cultural Revolution (1966-1976) are more "marked" than recent ones. It is argued that the shaping and re-shaping of China English is a reflection of the changing political, ideological and economic priorities of the nation.
\end{abstract}

Keywords: China English, ideology, Beijing Review

\section{Introduction}

With its estimated 300 million learners (according to figures released by Xinhuanet.com), English is the most popular foreign language in China. It is a compulsory subject in most secondary and tertiary institutions; the 2008 Olympic Games further spurred new fever in learning English. Its fast growth in popularity is partially the result of globalization, and partially the effect of the language policy that made the command of English a huddle requirement for promotion and academic development. Not only is English highly pursued, but it has also come to terms with its own distinctive features, shaping into a new performance variety (China English) which, according to some researchers (e.g. Chen \& $\mathrm{Hu}, 2006$ ), has the potential to be recognized in and outside China.

However, the current form of China English is by no means similar to what it used to be several centuries ago. Even briefly flipping English magazines several decades ago reveals remarkable contrast. This paper looks into the issue by making a diachronic comparison of Beijing Review, the first English news magazine in the PRC. First published in 1958, under the name Peking Review, it was intended to introduce to the international community the new image of China (Cheng, 1982). In January 1979, the name of the magazine was changed into Beijing Review, in accordance with the government's promotion of pinyin over the Wade-Giles system. In recent years, the magazine still has a considerable subscription in the international market. However, it now also targets national market, where the magazine is read by English learners and by officials dealing with foreign affairs.

The focus of this paper is the contrast of China English pre and post the Open Door Policy. In the 1950s, China English emerged as an expression of the PRC's new ideology. English, it was understood, should be used to serve the revolution (Cheng, 1982, p.125). This function was especially paramount during the Cultural Revolution (1966-1976), when the country's concern of independence and ideological purity was paramount (Ross, 1993, pp.36-40). Following the Open Door Policy in the 1980s, the country's concern over economic prosperity preceded that of ideology (Ross, 1993, pp.3660). With the change in policy, the functions of China English changed as well. China English was considered the gateway to Western science and technology, and for foreign countries to gain knowledge about China. As a result of the shift in its function, the image of China English also changed. This paper illustrates how these changes and shifts are reflected in Beijing Review. In order to draw a framework of the discussion, the following part briefly discusses the perceived characteristics of China English.

\section{Characteristics of China English}

According to previous research (Cheng, 1982; Kirkpatrick \& Xu, 2002), China English in the political register has the following characteristics: loan words and loan translations from Chinese, connotation changes, semantic shifts, and a distinct style of discourse. This section discusses these features with illustrations of excerpts from Beijing Review. In all the excerpts, boldface, italics and annotations in brackets are original; underlines are added by the author for emphasis. 


\subsection{Loan words}

Loan words, elsewhere referred to as "direct loans" (McArthur, 2002, p.357), are borrowings from Chinese with both the word's meaning and form. In Beijing Review, such words appear in pinyin (Romanized Chinese), usually in italics to mark their distinct origin, and are in most cases annotated.

\section{Excerpt 1}

What do ordinary Chinese people spend their money on, apart from chai mi you yan (fuel, rice, edible oil and salt), the basic necessities that keep them alive?

(Beijing Review, Jan 1, 2004)

In the excerpt above, chai mi you yan is an idiom in Chinese, which literally means "wood, rice, cooking oil and salt". The word is annotated with a literal translation in the brackets, followed by a free translation as the peripheral dependent ("the basic necessities that keep them alive"). Such an arrangement is worth noting, as it indicates that the loan word is not yet an established expression in China English. In Beijing Review, most loan words in China English are annotated. Other examples include: lao bai xing (the common people), ta tse pao (wall newspaper opinions written in boldface, poster-size Chinese characters), Renmin Ribao (People's Daily), etc.

\subsection{Loan translations}

Loan translations are also borrowings from Chinese, except that the Chinese words are directly translated into corresponding words in English. Such words or phrases usually have their origins in Chinese idioms, culture, or political movements (McArthur, 2002, p.357). As they express a distinct culture or ideology, loan translations are usually not comprehensible for people without relevant background knowledge (Cheng, 1982, p.133). These words are usually not annotated in Beijing Review.

\section{Excerpt 2}

If one only talks about "two systems" while neglecting the "one country", the high degree of autonomy would be like water without a source.

(Beijing Review, Jan 1, 2004)

The excerpt above appears in a political commentary about Hong Kong. Two systems and one country come from the phrase yi guo liang zhi (one country two system), an expression of late Chinese premiere Deng Xiaoping's proposal of the administration of Taiwan and Hong Kong. With one country referring to China, and two systems referring to socialism and capitalism, the phrase indicates the government's policy of claiming sovereignty over these two areas, while being willing to keep their current statuses (as "capitalist" areas). In the main clause, water without a source, a loan translation from the idiom wu yuan zhi shui, is a metaphor in Chinese indicating sayings or doings without any basis.

Other examples of loan translation include Spring Festival (Chinese New Year, loan translation from Chunjie), Mao Zedong Thought (political ideas of late Chinese leader Mao Zedong, loan translation from Mao Zedong Sixiang), Proletarian Cultural Revolution (the political movement in China from 1966-1976, loan translation from Wuchan Jieji Wenhua Da Geming), the Red Army (the Chinese Communist Army, loan translation from Hongjun) etc.

\subsection{Connotation change}

Connotation change refers to the shift of the word's associative meaning. Usually, such changes are related to ideology. Some words with negative associations can have a positive connotation in China English; while some originally neutral words can acquire either positive (such as proletariat, socialism, revolution) or negative (such as capitalism, revisionism) meanings. Lee-Wong (1997), for instance, provides a detailed account of how comrade, a neutral word in English, was used as an honorary address term during the Cultural Revolution. Excerpt 3 is an illustration of such usage.

\section{Excerpt 3}

On May 1, Chairman Mao, the most beloved and respected great leader of Chinese and the world's people, and his close comrade-in-arms Comrade Lin Piao joined with three million revolutionary people in Peking to celebrate International Labor Day...

(Peking Review, May 5, 1967)

\section{Excerpt 4}

In the New Year the whole Party, the whole army and the people throughout the country should ... further consolidate the dictatorship of the proletariat...

(Peking Review, Jan 7, 1972)

Excerpt 4 above appears the New Year's political commentary for 1972. In this excerpt, both dictatorship and proletariat have positive connotations. 
2.4 Semantic shifts

In China English, semantic shifts usually involve metaphorical shifts (where words have fixed metaphorical interpretations) and differentiations (where the meanings of words are narrowed according to the context). In the following excerpt, line is used metaphorically to refer to political positions. In the following clause, grasp further extends the "line" metaphor, meaning to adopt the correct position.

\section{Excerpt 5}

Chairman Mao points out: "The line is the key link, once it is grasped, everything falls into place."

(Peking Review, Jan 7, 1972)

Road, as in socialist road and capitalist road, is another example of metaphorical shift, where it is used to indicate ideological positions. Other examples of differentiation involve consciousness (political awareness), struggle-criticism (a form of mass movement during the Cultural Revolution), transformation (the conversion of someone who is in favor of capitalism) etc.

2.5 Discourse style

China English in the political register exhibits two paramount features in its discourse style: the use of extensive modifiers for leaders and profuse quotes form Mao Zedong's speech (see Cheng, 1982).

Excerpt 6

Our great teacher, great leader, great supreme commander and great helmsman Chairman Mao...

(Peking Review, Jan 1, 1967)

\section{Excerpt 7}

Our most respected and beloved great teacher and great leader Chairman Mao and his close comrade-in-arms Vice-Chairman Lin Piao received revolutionary fighters from various parts of China on the afternoon of May 19.

(Peking Review, May 23, 1969)

Excerpts 6 and 7 both contain extensive uses of honorary titles for late Chinese leader Mao Zedong. In excerpt 6, helmsman has undergone a metaphorical shift, indicating the leader in political movements.

\section{Excerpt 8}

Chairman Mao has taught us: "To lead means not only to decide general and specific policies but also to devise correct methods of work. Even with correct general and specific policies, troubles may still arise if methods of word are neglected."

Chairman Mao has also taught us: "It is not enough to set tasks, we must also solve problem of the methods for carrying them out. If our task is to cross a river, we cannot across it without a bridge or a boat. Unless the bridge or boat problem is solved, it is idle to speak of crossing the river. Unless the problem of the method is solved, talk about the task is useless."

(Peking Review, Nov 14, 1969)

\section{Excerpt 9}

The past year has been a year of great victory in carrying out education in ideology and political line throughout the Party and among the people of the whole country.

(Peking Review, Jan 7, 1972)

\section{Excerpt 10 (President Nixon's Toast)}

Chairman Mao has written, "So many deeds cry out to be done, and always urgently; the world rolls on, Time presses. Ten thousand years are too long, Seize the day, seize the hour!"

Excerpts 8, 9 and 10 all contain profuse quotes from Mao Zedong's works and speeches. During the Cultural Revolution, all quotes of Mao Zedong's words were printed in boldface, whether they appear in newspapers or books, in Chinese or in other languages. Excerpt 9 may seem unusual, where a piece of Mao's phrase, barely acknowledged, was interposed in the flow of a sentence. However, such usages were not rare texts produced during the Cultural Revolution. Excerpt 10 is a piece of President Nixon's speech during this visit in China in 1972 published by the Chinese media. It is worth noting that the US president also quoted Mao's words in his speech. 


\section{China English before and after the Open Door Policy}

This part compares excerpts from articles in Beijing Review during the Cultural Revolution and in recent years, in terms of the characteristics listed above, in an effort to illustrate the changing image of China English.

\section{Excerpt 11}

On May 1, Chairman Mao, the most beloved and respected great leader of Chinese and the world's people, and his close comrade-in-arms Comrade Lin Piao joined with three million revolutionary people in Peking to celebrate International Labor Day - a festival of solidarity and militancy of the world's proletariat and other working people.

(Peking Review, May 5, 1967)

\section{Excerpt 12}

When Premier Wen Jiaobao visited Chen Lianfu and Wang Dongyun, a couple who were quarantined due to the bird flu virus, during this year's Spring Festival in Shifuozhen Town, Hubei Province, the couple were so overwhelmed that they didn't hear their leader ask them to take off the protective masks they were wearing.

(Beijing Review, Feb 26, 2004)

Excerpts 11 and 12 below are respectively taken from reports of Chinese leaders at different times: one during the Cultural Revolution, and one in 2004. The 1967 excerpt displays several distinct features of China English. Extensive honorary titles (the most beloved and respected great leader of Chinese and the world's people) are used as the peripheral dependent modifying Chinaman Mao. The word comrade is capitalized, indicating its use as a special honorary title. Both militancy and proletariat have acquired positive connotations. Militancy is associated with the communists' high spirits and determination for revolution, whereas proletariat refers to workers and poor peasants, which are classified into the most politically advanced social class in China.

These characteristics are less evident in excerpt 12. Premier Wen Jiabao is not modified by any honorary title. The Chinese features in this excerpt only involve a loan translation (Spring Festival, translated from Chunjie) and several proper names.

\section{Excerpt 13}

Later this month, Chinese President Xi Jinping will make his first state visit to the United States since assuming office. The trip will undoubtedly give a strong boost to Sino-U.S. relations and demonstrate the promising prospect for building a new model of major country relationship between the two nations.

(Beijing Review, Sep 17, 2015)

In excerpt 13, Xi Jinping, the chief-of-state of China, is referred to as Chinese President. Note that in excerpt 11, Mao Zedong, who was in the same position as $\mathrm{Xi}$, is referred to as Chairman Mao. Although their Chinese titles are the same (zhuxi), the English translation is altered to accommodate with the Western norms.

\section{Excerpt 14}

It was a wintry afternoon when the young revolutionaries of the Dongfanghong (East Is Red) Long March Detachment from Shanxi Province's Taiyuan Industrial College reached Erhshihlipu Village. As they approached its northern outskirts they saw some commune members building a ditch.

(Peking Review, Jan 6, 1967)

\section{Excerpt 15}

Li Xuan is a gentle lady with a sunny disposition and has been well and truly bitten by the travel bug. "This year I plan to travel to Britain and Canada," said Li Xuan, a 26-year-old manager of a joint-venture advertisement company in Beijing. Unlike the majority of traditional Chinese woman of her age, Li (using surname as the address term, accommodation with English conventions) has a more Western style character that fit in well with her love for travel.

(Beijing Review, Jan 1, 2004)

Similar to previous examples, the excerpt during the Cultural Revolution shows more Chinese characteristics than the 2004 excerpt. In excerpt 14, revolutionaries has undergone a semantic shift: it doesn't necessarily refer to the people who are carrying out a revolution, but is used as a general honorary title. Long March is a loan translation from Chang Zheng, the Chinese Communist Party's famous march during the civil war. The meaning of commune is also shifted. Elsewhere referred to as co-op, the word is used specifically to indicate the system of joint-ownership of farms and commodities, which is the result of the country's reformation of farmland ownership in the 1950s.

In excerpt 15, there is little evidence of such characteristics. It is also interesting to note that the surname $L i$ is used as an address term, which is at odds with the Chinese convention of using the full name (Li Xuan). This again shows how China English accommodates with norms in Western culture. In the 1990s, the Chinese government issued guides for making the propaganda "attractive, entertaining and inspiring" (Brady, 2008, p.74). English media in China since had 
more freedom in terms of lexical choice, as long as the ideological essence is preserved. In their analysis of texts from China Daily, Guo and Huang (2002) also find that there is less obligation to echo terminology of the Chinese Communist Party. Guo and Huang (2002) attribute the change, among others, to the necessity of building audience rapport and the government's aspiration of having its voice heard overseas.

\section{The changing image of China English}

The examples discussed above are by no means exclusive. However, they seem indicate a tendency in China English in the political register: it is changing from a highly marked variety during the Cultural Revolution to one that is less marked, and has more commonalities with norms in Western culture (EIL, see Modiano, 1999). In the framework of World Englishes, such a change can be interpreted with relation to the function of the China English, which is again shaped by the policy of the country.

In her discussion of codification, Pakir (1997) identifies two functions coding a new variety may serve: the Separatist Function of marking the country's independence and distinctiveness and the Participatory Function of getting involved in the international community. The conceptualization is relevant to the present discussion, as China English is also expected to perform these two functions, except that they receive differentiating emphasis at different times.

During the Cultural Revolution, as government policies were devoted to the country's independence and ideology purity, the Separatist Function received paramount emphasis. China English in the political register was used to express the PRC's distinctiveness in ideology and political systems. As the slogan indicates, English should be used to "serve the revolution" (Cheng, 1982, p.125). Accordingly, changes were made to the variety so that it fit the political situation of the PRC: loanwords and loan translations were introduced to facilitate the expression of the country's particular situation; connotation changes occurred to indicate a distinct value system. China English back then, in this sense, was a variety using the "media" (the communicative code, see Kachru, 1994, pp. 6-7) of English to express the "message" (the cultural content, see Kachru, 1994, pp.6-7) of China. Cheng (1982, p.136), for example, noted that a 1974 English textbook in China contained articles exclusively relating to the Chinese society.

Following the Open Door Policy in the 1980s, the chief concern of the nation shifted from ideology and politics to economic prosperity. The functions of China English changed accordingly. The variety is now considered the gateway to advanced technology and international friendship (Cheng, 1982). As a result, the image of China English has changed has well. Loan words and loan translations are not as frequent, and whereby they occur, tend to be accompanied by annotations, as they might be difficult to understand for international readers. Other distinct features, such as extensive honorary titles for the leader, decline as well. In addition, the variety starts to show some accommodations with Western norms. Changes in China English could be interpreted as a subtle indication of the country's embracement of globalization.

\section{Conclusion}

The paper discusses China English in the political register by analyzing texts from the first English news magazine in the PRC, Beijing Review. Comparisons are made between texts written during the Cultural Revolution and texts produced after the Open Door Policy. It is noted that while ideological scaffolding is in place in both cases, texts produced after the Open Door Policy tend to be less marked with features dictated by communist ideology. This change occur due to the government's incentive of making propaganda attractive, so as to be better received by audience at home and abroad. As a result, editors enjoy more freedom in using the "media", as long as the "message" is in line with the political ideology. The findings are interpreted with relation to the Separationist and Participatory Functions of English varieties, arguing that in the era of globalization, the Participatory Function of China English in the political register becomes more prominent than it was during the Culture Revolution.

\section{References}

Brady, A. (2008). Marketing dictatorship: Propaganda and thought work in contemporary China. Lanham, MD: Rowman \& Littlefield.

Cheng, C. C. (1982). Chinese varieties of English. In B. B. Kachru (Ed.), The other tongue: English across cultures (pp.162-177). Urbana; Chicago; London: University of Illinois Press.

Chen, M.L., \& Hu, X.Q. (2006). Towards the acceptability of China English at home and abroad. Changing English, 13(2), 231-240.

Guo, Z. S. and Huang, Y. (2002). Hybridized discourse: Social openness and functions of English media in post-Mao China. World Englishes 21(2), 217-30

Lee-Wong, S. M. (1997). Undoing some effects of the Cultural Revolution-Chinese address forms. In M. Clyne (Ed.), Undoing and redoing corpus planning (pp. 95-115). Berlin: Mouton de Gruyter.

McArthur, T. (2002). Oxford guide to World Englishes. Oxford: OUP.

Kachru, B. B. (1994). The speaking tree: A medium of plural canons. In J. E. Alatis (Ed.), Georgetown University round table on languages and linguistics 1994 (pp 6-22). Washington, DC: Georgetown University Press.

Kirkpatrick, A., \& Xu, Z. (2002). Chinese pragmatic norms and “China English”. World Englishes, 21 (2), $269-279$.

Modiano, M. (1999). International English in the global village. English Today, 15 (2), 22-28.

Pakir, A. (1997). Standards and codification for World Englishes. In L. E. Smith \& M. L. Forman (Eds.), World Englishes 2000 (pp. 182-203). Honolulu: University of Hawai'i Press.

Ross, H. A. (1993). China learns English: language teaching and social change in the People's Republic. New Haven; London: Yale University Press. 